\title{
Efficacy and Anticarcinogenic Activity of Ribavirin Combination Therapy for Hepatitis C Virus-Related Compensated Cirrhosis
}

\author{
Norio Akuta ${ }^{a}$ Fumitaka Suzuki ${ }^{a} \quad Y$ uya Seko ${ }^{a}$ Yusuke Kawamura ${ }^{a}$ \\ Hitomi Sezaki $^{a}$ Yoshiyuki Suzuki ${ }^{a}$ Tetsuya Hosaka ${ }^{a}$ Masahiro Kobayashia \\ Mariko Kobayashi $^{b}$ Satoshi Saitoh ${ }^{a}$ Yasuji Arase $^{a}$ Kenji Ikeda ${ }^{a}$ \\ Hiromitsu Kumada ${ }^{a}$ \\ a Department of Hepatology, Toranomon Hospital, and Okinaka Memorial Institute for Medical Research, and \\ ${ }^{\text {b } L i v e r ~ R e s e a r c h ~ L a b o r a t o r y, ~ T o r a n o m o n ~ H o s p i t a l, ~ T o k y o, ~ J a p a n ~}$
}

\section{Key Words}

Hepatitis C virus - Interferon - Ribavirin - Hepatocellular

carcinoma $\cdot$ Cirrhosis $\cdot$ Biochemical response

\section{Abstract}

Objective: Anticarcinogenic activity of ribavirin combination therapy for hepatitis $C$ virus (HCV)-related compensated cirrhosis is still unclear. Methods: In study 1, in 157 consecutive patients with HCV-related compensated cirrhosis, treatment efficacy with interferon plus ribavirin therapy was evaluated for 48 weeks of HCV genotype $1 \mathrm{~b}$ (HCV-1b) or 24 weeks of HCV-2a/2b. In study 2, in 185 consecutive patients with HCV-related compensated cirrhosis, who showed no sustained virological response following the first course of interferon monotherapy, hepatocarcinogenesis rates were evaluated according to the additional treatment, and they were classified into three groups: no treatment, interferon monotherapy, and ribavirin combination therapy. Results: In study 1, in HCV-1b, rates of sustained virological response and sustained biochemical response were 21 and 56\%, respectively. In HCV-2a/2b, rates of sustained virological response and sustained biochemical response were 70 and

\section{KARGER}

Fax +4161306 1234

E-Mail karger@karger.ch

www.karger.com
(C) 2012 S. Karger AG, Basel

$0300-5526 / 13 / 0561-0037 \$ 38.00 / 0$

Accessible online at:

www.karger.com/int
$78 \%$, respectively. In HCV-1b, sustained biochemical response rates were significantly higher than those of sustained virological response. In study 2, the hepatocarcinogenesis rates in ribavirin combination therapy were significantly lower than those in interferon monotherapy and no treatment, respectively. Conclusion: Ribavirin combination therapy for HCV-related compensated cirrhosis reduces the risk of hepatocarcinogenesis in comparison with interferon monotherapy, and higher rates of sustained biochemical response might be associated with lower hepatocarcinogenesis rates.

Copyright $\odot 2012$ S. Karger AG, Basel

\section{Introduction}

Hepatitis C virus (HCV) usually causes chronic infection, which can result in chronic hepatitis, liver cirrhosis, and hepatocellular carcinoma [1-5]. The life expectancy of patients with HCV-related cirrhosis is largely influenced by the development of hepatocellular carcinoma during the clinical course [3]. Because an effective and curative therapy for hepatocellular carcinoma remains 
Table 1. Profile and laboratory data at the start of ribavirin combination therapy in 157 patients with $\mathrm{HCV}$-related compensated cirrhosis (study 1)

$\begin{array}{lc}\text { Demographic data } & \\ \text { Patients, } \mathrm{n} & 157^{1} \\ \text { Sex (male/female), } \mathrm{n} & 105 / 52 \\ \text { Age, years } & 58(34-74) \\ \text { Laboratory data } & 69(7-235) \\ \quad \text { Serum aspartate aminotransferase, IU/1 } & 70(14-585) \\ \text { Serum alanine aminotransferase, IU/l } & 4,100(1,600-8,800) \\ \text { Leukocytes, } / \mathrm{mm}^{3} & 14.0(9.4-17.6) \\ \text { Hemoglobin, } \mathrm{g} / \mathrm{dl} & 11.3(6.1-32.2) \\ \text { Platelet count, } \times 10^{4} / \mathrm{mm}^{3} & 120 / 27 / 10 \\ \text { HCV genotype }(1 \mathrm{~b} / 2 \mathrm{a} / 2 \mathrm{~b}), \mathrm{n} & 6.1(3.9-7.5) \\ \text { Levels of viremia, log IU/ml } & \\ \text { Treatment } & 95(60.5 \%) \\ \text { Past history of interferon-based therapy, } \mathrm{n} & 110 / 47 \\ \text { PEG-IFN } \alpha-2 \mathrm{~b} / \mathrm{IFN} \alpha-2 \mathrm{~b}, \mathrm{n} & 10.7(2.7-15.1) \\ \text { Ribavirin dose, } \mathrm{mg} / \mathrm{kg} & \\ \text { Duration of treatment, weeks } & 48(1-48) \\ \quad \text { Genotype } 1 \mathrm{~b} & 24(5-24) \\ \quad \text { Genotype } 2 \mathrm{a} \text { or } 2 \mathrm{~b} & \end{array}$

Unless otherwise indicated, values represent median (range).

${ }^{1} 24$ of the 157 patients with HCV-related compensated cirrhosis in study 1 were also included in study 2 . They showed no sustained virological response following the first course of interferon monotherapy ( $\geq 24$ weeks) and were treated additionally with ribavirin combination therapy ( $\geq 24$ weeks).

limited at best, primary prevention of hepatocellular carcinoma in patients with chronic liver disease is of great importance at present.

Treatment of HCV-chronic hepatitis with interferon can induce viral clearance and marked biochemical and histological improvement [6,7]. Furthermore, previous studies showed that interferon monotherapy reduced the risk of hepatocellular carcinoma [8-10]. However, an extended analysis of the Hepatitis C Antiviral Long-Term Treatment against Cirrhosis (HALT-C) cohort recently showed that long-term peginterferon (PEG-IFN) monotherapy could not reduce the incidence of hepatocellular carcinoma among patients with advanced hepatitis C who did not achieve sustained virological response, and patients with cirrhosis who received PEG-IFN monotherapy had a lower risk of hepatocellular carcinoma than controls [11]. Thus, it is controversial whether interferon monotherapy for patients with liver cirrhosis might reduce hepatocarcinogensis. Furthermore, it is still unclear whether ribavirin combination therapy for patients with liver cirrhosis might reduce the risk of hepatocellular carcinoma, and there are also no reports on whether ribavirin combination therapy could reduce the risk in comparison with interferon monotherapy.

The present study investigated the efficacy and anticarcinogenic activity of ribavirin combination therapy for HCV-related compensated cirrhosis, especially in comparison with interferon monotherapy.

\section{Materials and Methods}

\section{Study Population}

Two retrospective cohort studies were performed to investigate treatment efficacy and anticarcinogenic activity of ribavirin combination therapy for HCV-related compensated cirrhosis.

In the study 1 cohort, 157 consecutive patients of HCV-related compensated cirrhosis were recruited into the study protocol of interferon (PEG-IFN $\alpha-2 b$ or IFN $\alpha-2 b$ ) plus ribavirin combination therapy for 48 weeks of HCV genotype $1 \mathrm{~b}$ (HCV-1b) or 24 weeks of HCV-2a/2b, from 2001 to 2010 at Toranomon Hospital. In this retrospective study the rates of sustained virological response [HCV-RNA negativity at 24 weeks after the completion of therapy based on the COBAS TaqMan HCV test (Roche Diagnostics)] were evaluated as well as sustained biochemical response [normal level of serum alanine aminotransferase at 24 weeks after the completion of therapy (6-50 IU/l)]. Treatment efficacy was evaluated by intention-to-treat (ITT) analysis classified as treatment failure in patients who could not complete the treatment regimen and per protocol (PP) analysis. Table 1 summarizes the profiles and data of the 157 patients at the commencement of combination therapy with interferon plus ribavirin in study 1 . They included 105 men and 52 women aged 34-74 years (median 58 years). 110 (70.1\%) patients received PEG-IFN $\alpha-2 b$ plus ribavirin, and the remaining 47 (29.9\%) patients received IFN $\alpha$-2b plus ribavirin. They received PEG-IFN $\alpha-2 b$ at a median dose of $1.3 \mu \mathrm{g} /$ $\mathrm{kg}$ (range $0.5-1.9 \mu \mathrm{g} / \mathrm{kg}$ ) subcutaneously each week or IFN $\alpha-2 \mathrm{~b}$ at a median dose of 6 million units (range 3-6 million units) intramuscularly each day $(7$ times per week for the initial 2 weeks followed by 3 times per week). They also received oral ribavirin at a median dose of $10.7 \mathrm{mg} / \mathrm{kg}$ (range $2.7-15.1 \mathrm{mg} / \mathrm{kg}$ ) daily. In 56 of the 157 (35.7\%) patients, the dose of ribavirin was reduced during treatment due to a fall in hemoglobin concentration. The median total duration of treatment in 120 patients of HCV-1b was 48 weeks (range 1-48 weeks), and that in 37 patients of genotype $2 \mathrm{a}$ or $2 \mathrm{~b}$ was 24 weeks (range 5-24 weeks).

In the study 2 cohort (fig. 1), 185 consecutive patients of HCVrelated compensated cirrhosis, who showed no sustained virological response following at the first course of interferon monotherapy ( $\geq 24$ weeks) from 1987 to 2010 at Toranomon Hospital, were recruited. Hepatocarcinogenesis rates were evaluated according to the additional treatment (second course of treatment), and were classified into three groups: no treatment (106 patients), interferon monotherapy ( $\geq 24$ weeks; 55 patients), and ribavirin combination therapy ( $\geq 24$ weeks; 24 patients). 106 patients without treatment did not receive the additional treatment because of concerns about adverse effects, lack of time for treatment, physician recommendation based on the appearance of depression and car- 
First course of treatment

Patients of HCV-related compensated cirrhosis, who showed no sustained virological response following interferon monotherapy ( $\geq 24$ weeks) $(n=185)$

Ribavirin combination therapy ( $\geq 24$ weeks) $(n=24)^{*}$ response following the first course of interferon monotherapy ( $\geq 24$ weeks), were recruited. Hepatocarcinogenesis rates were evaluated according to the additional treatment (second course of treatment), and patients were classified into three groups: no treatment, interferon monotherapy ( $\geq 24$ weeks), and ribavirin combination therapy ( $\geq 24$ weeks). ${ }^{*} 24$ of 157 patients with HCV-related compensated cirrhosis in study 1 were also included in study 2 .

diopulmonary disease during and after the first course of interferon monotherapy or the lower levels of serum alanine aminotransferase. The median follow-up time, from the end of the first course of interferon monotherapy until the last visit, was 6.4 years (range $0.0-21.0$ years). 24 of the 157 patients in study 1 were also included in study 2; they showed no sustained virological response following the first course of interferon monotherapy $(\geq 24$ weeks) and were treated additionally with ribavirin combination therapy ( $\geq 24$ weeks).

At the additional treatment of interferon monotherapy, 43 patients $(78.2 \%)$ received IFN $\alpha$ alone, and the remaining 12 patients $(21.8 \%)$ received IFN $\beta$ alone. They received interferon monotherapy including initial aggressive induction therapy (every day for 8 weeks followed by 3 times per week), with a median treatment duration of 44 weeks (range 24-382 weeks) at a median dose of 3 million units (range 3-10 million units) intramuscularly each day.

At the additional treatment of ribavirin combination therapy, 11 patients $(45.8 \%)$ received PEG-IFN $\alpha-2 b$ plus ribavirin, and the remaining 13 patients $(54.2 \%)$ received IFN $\alpha-2 b$ plus ribavirin. They received PEG-IFN $\alpha-2 \mathrm{~b}$ at a median dose of $1.5 \mu \mathrm{g} / \mathrm{kg}$ (range $0.8-1.7 \mu \mathrm{g} / \mathrm{kg}$ ) subcutaneously each week or IFN $\alpha-2 \mathrm{~b}$ at a median dose of 6 million units (range 3-6 million units) intramuscularly each day ( 7 times per week for the initial 2 weeks followed by 3 times per week), with a median treatment duration of 26 weeks (range 24-48 weeks). They also received oral ribavirin at a median dose of $11.0 \mathrm{mg} / \mathrm{kg}$ (range $3.0-12.5 \mathrm{mg} / \mathrm{kg}$ ) daily.

In the present studies, the patients were selected based on the following criteria. (1) Patients had compensated cirrhosis, but no decompensated cirrhosis or hepatocellular carcinoma. The diagnosis of compensated cirrhosis was based on clinical features (absence of signs for decompensation of ascites, encephalopathy, or gastrointestinal bleeding), laboratory tests, and peritoneoscopy or liver biopsy. (2) Patients were negative for hepatitis B surface antigen (radioimmunoassay, Dainabot, Tokyo, Japan), positive for anti-HCV (third-generation enzyme immunoassay, Chiron Corp., Emerville, Calif., USA), and positive for HCV-RNA by qualitative or quantitative analysis. (3) Patients were free of coinfection with human immunodeficiency virus. (4) Lifetime cumulative alcohol intake was $<500 \mathrm{~kg}$ (mild to moderate alcohol intake). (5) Patients were free of other types of hepatitis, including hemochromatosis, Wilson disease, primary biliary cirrhosis, alcoholic liver disease, and autoimmune liver disease. (6) Each patient signed a consent form of the study protocol that had been approved by the human ethics review committee.

\section{Laboratory Investigations}

Blood samples were frozen at $-80^{\circ}$ within $4 \mathrm{~h}$ of collection and were not thawed until used for testing. HCV genotype was determined by PCR using a mixed primer set derived from nucleotide sequences of the NS5 region [12]. HCV-RNA quantitative analysis was measured by branched DNA assay version 2.0 (Chiron Corp., Emeryville, Calif., USA), AMPLICOR GT HCV Monitor version 2.0 using the 10-fold dilution method (Roche Molecular Systems Inc., Pleasanton, Calif., USA), or COBAS TaqMan HCV test (Roche Diagnostics, Tokyo, Japan). High viral load of viremia levels was defined as branched DNA assay $\geq 1.0 \mathrm{MEq} / \mathrm{ml}$, AMPLICOR GT HCV Monitor $\geq 100 \times 10^{3} \mathrm{IU} / \mathrm{ml}$, or COBAS TaqMan $\mathrm{HCV}$ test $\geq 5.0 \log \mathrm{IU} / \mathrm{ml}$. Low viral load was defined as branched DNA assay $<1.0 \mathrm{MEq} / \mathrm{ml}$, AMPLICOR GT HCV Monitor $<100 \times$ $10^{3} \mathrm{IU} / \mathrm{ml}$, or COBAS TaqMan HCV test $<5.0 \mathrm{log} \mathrm{IU} / \mathrm{ml}$. The lower limit of HCV-RNA qualitative analysis (Amplicor, Roche Diagnostics, Mannheim, Germany) was 100 copies $/ \mathrm{ml}$, and that of 
Fig. 2. In 157 patients with HCV-related compensated cirrhosis treatment efficacy with interferon plus ribavirin therapy was evaluated for 48 weeks of HCV genotype $1 \mathrm{~b}$ or 24 weeks of genotype $2 \mathrm{a} / 2 \mathrm{~b}$. In HCV genotype $1 \mathrm{~b}$, rates of sustained biochemical response (SBR) were significantly higher than those of sustained virological response (SVR; ITT analysis, $\mathrm{p}<0.001$, and $\mathrm{PP}$ analysis, $\mathrm{p}=0.028$ ).

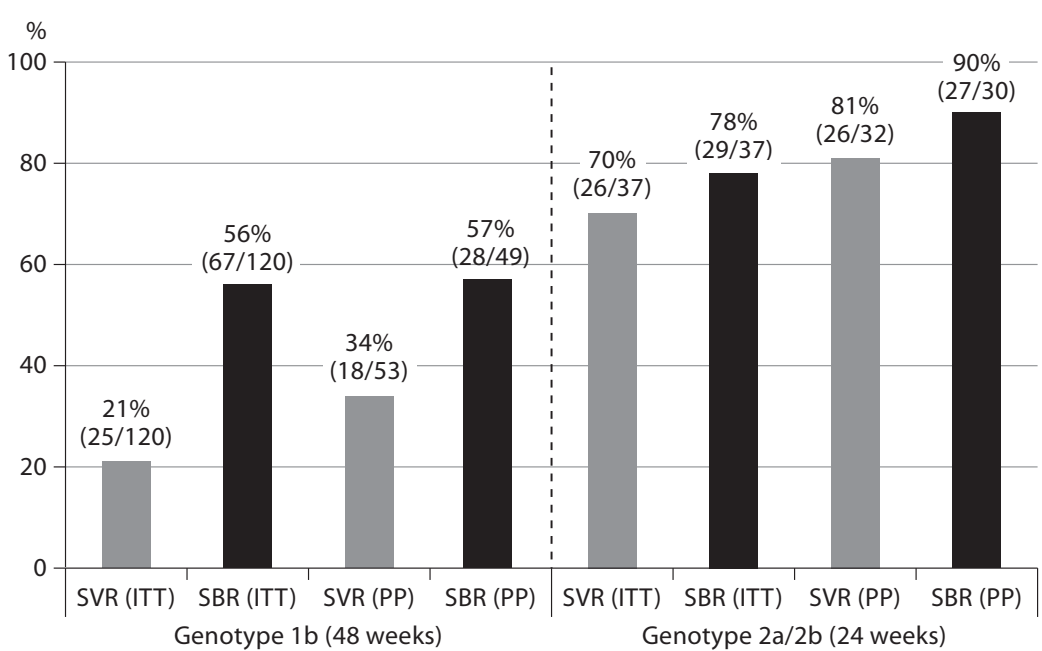

Genotype $2 \mathrm{a} / 2 \mathrm{~b}$ (24 weeks)
COBAS TaqMan HCV test was $1.2 \log \mathrm{IU} / \mathrm{ml}$. The undetectable samples by HCV-RNA qualitative analysis or COBAS TaqMan $\mathrm{HCV}$ test were defined as negative HCV-RNA.

\section{Follow-Up and Diagnosis of Hepatocellular Carcinoma}

Clinical and laboratory assessments were performed at least once every month before, during, and after treatment. Adverse effects were monitored clinically by careful interviews and medical examination at least once every month. Patient compliance with treatment was evaluated with a questionnaire. Blood samples were also obtained at least once every month before, during, and after treatment, and were also analyzed for levels of serum alanine aminotransferase and HCV-RNA at various time points.

Patients were examined for hepatocellular carcinoma by abdominal ultrasonography every 3-6 months. If hepatocellular carcinoma was suspected based on ultrasonographic results, additional procedures, such as computed tomography, magnetic resonance imaging, abdominal angiography, and ultrasonography-guided tumor biopsy if necessary, were used to confirm the diagnosis.

\section{Statistical Analysis}

$\chi^{2}$ test, Fisher's exact probability test, and Mann-Whitney's U test were used to compare the background characteristics between groups. Multiple comparisons were examined by the Bonferroni test. The cumulative hepatocarcinogenesis rates were calculated using the Kaplan-Meier technique, and differences between the curves were tested using the log-rank test. Statistical analysis of the hepatocarcinogenesis rates according to groups was calculated using the period from the end of the first course of interferon monotherapy until the appearance of hepatocellular carcinoma or until the last visit or until the start of the third course of interferon-based treatment. Stepwise Cox regression analysis was used to determine independent predictive factors that were associated with hepatocarcinogenesis. The hazard ratio (HR) and 95\% confidence interval were also calculated. Potential predictive factors associated with hepatocarcinogenesis included the following 13 variables: age, sex, serum aspartate aminotransferase, serum alanine aminotransferase, platelet count, total cholesterol, high-density lipoprotein cholesterol, low-density lipoprotein cholesterol, triglycerides, HCV genotype, levels of viremia, total duration of additional treatment, and group of additional treatment. Each variable was transformed into categorical data consisting of two simple ordinal numbers for univariate and multivariate analyses. All $\mathrm{p}$ values $<0.05$ and $<0.1$ by the twotailed test were considered significant $(p<0.05)$ and marginally significant $(p<0.1)$, respectively. Variables that achieved statistical significance $(\mathrm{p}<0.05)$ on univariate analysis were tested by multivariate Cox proportional hazard model to identify significant independent factors. Statistical comparisons were performed using the SPSS software (SPSS Inc., Chicago, Ill., USA).

\section{Results}

\section{Efficacy of Ribavirin Combination Therapy (Study 1)}

Treatment efficacy of a 48-week regimen of interferon plus ribavirin combination therapy in 120 patients infected with HCV-1b was evaluated. In ITT analysis, rates of sustained virological response and sustained biochemical response were 21\% (25 of 120 patients) and 56\% (67 of 120 patients), respectively. In the PP analysis, rates of sustained virological response and sustained biochemical response were 34\% (18 of 53 patients) and 57\% (28 of 49 patients), respectively (fig. 2). In both analyses, rates of sustained biochemical response were significantly higher than those of sustained virological response (ITT analysis, $\mathrm{p}<0.001$, and PP analysis, $\mathrm{p}=0.028$ ). 
Table 2. Profile and laboratory data of 185 patients with HCV-related compensated cirrhosis according to additional treatment groups (study 2)

No treatment

Interferon mono-

Ribavirin combination

therapy ( $\geq 24$ weeks) therapy $^{1}$ ( $\geq 24$ weeks)

Demographic data

Patients, $n$

Sex (male/female), $\mathrm{n}$

Age, years

Laboratory data

Serum aspartate aminotransferase, IU/1

Serum alanine aminotransferase, IU/l

Platelet count, $\times 10^{4} / \mathrm{mm}^{3}$

Total cholesterol, $\mathrm{mg} / \mathrm{dl}$

High-density lipoprotein cholesterol, mg/dl

Low-density lipoprotein cholesterol, $\mathrm{mg} / \mathrm{dl}$

Triglycerides, mg/dl

HCV genotype (1b/2a or $2 b), n$

Levels of viremia (high viral load/low viral load), $n$

Additional treatment

Duration of additional treatment, weeks

Sustained virological response (ITT), $\mathrm{n}$

Sustained biochemical response (ITT), $\mathrm{n}$

106
$64 / 42$
$56(30-75)^{\mathrm{a}}$
$75(26-285)$
$92(17-400)$
$10.7(2.5-18.2)^{\mathrm{c}}$
$165(103-273)^{\mathrm{h}}$
$46(25-93)$
$93(38-168)$
$96(36-437)$
$70 / 36$
$84 / 16$

$-$

$-$

$-$

$\begin{array}{lc}55 & 24 \\ 37 / 18 & 20 / 4 \\ 56(35-76)^{\mathrm{b}} & 51(34-68) \\ & \\ 83(35-213) & 62(30-160) \\ 104(30-316) & 93(36-250) \\ 10.8(5.7-19.8)^{\mathrm{d}} & 13.0(5.2-23.5) \\ 152(101-220) & 160(111-211) \\ 43(21-65) & 47(28-56) \\ 87(45-139) & 100(34-135) \\ 80(51-215) & 108(52-206) \\ 39 / 16 & 17 / 7 \\ 37 / 15^{\mathrm{e}} & 24 / 0 \\ & \\ 44(24-382)^{\mathrm{f}} & 26(24-48) \\ 11(20 \%) & 7(29 \%) \\ 25(45 \%)^{\mathrm{g}} & 16(67 \%)\end{array}$

Unless otherwise indicated, values represent median (range).

Demographic data and laboratory data, at the start of the first course of interferon monotherapy, are shown.

${ }^{\mathrm{a}} \mathrm{p}=0.013,{ }^{\mathrm{b}} \mathrm{p}=0.030,{ }^{\mathrm{c}} \mathrm{p}=0.002,{ }^{\mathrm{d}} \mathrm{p}=0.015,{ }^{\mathrm{e}} \mathrm{p}=0.006$, ${ }^{\mathrm{f}} \mathrm{p}=0.044,{ }^{\mathrm{g}} \mathrm{p}=0.083$ compared with ribavirin combination therapy by Bonferroni test, Mann-Whitney $U$ test, or $\chi^{2}$ test. ${ }^{\mathrm{h}} \mathrm{p}=$ 0.039 compared with interferon monotherapy by Bonferroni test.
${ }^{1} 24$ of 157 patients with HCV-related compensated cirrhosis in study 1 were also included in study 2 . They showed no sustained virological response following the first course of interferon monotherapy ( $\geq 24$ weeks), and were additionally treated with ribavirin combination therapy ( $\geq 24$ weeks).
Treatment efficacy of a 24-week regimen of interferon plus ribavirin combination therapy in 37 patients infected with HCV-2a or $2 \mathrm{~b}$ was evaluated. In the ITT analysis, rates of sustained virological response and sustained biochemical response were $70 \%$ (26 of 37 patients) and 78\% (29 of 37 patients), respectively. In the PP analysis, rates of sustained virological response and sustained biochemical response were $81 \%$ ( 26 of 32 patients) and $90 \%$ ( 27 of 30 patients), respectively (fig. 2). In both analyses, rates of the sustained biochemical response were not significantly higher than those of the sustained virological response.

\section{Profile, Laboratory Data, and Efficacy according to \\ Additional Treatment Groups (Study 2)}

Profile and laboratory data, at the start of the first course of interferon monotherapy of 185 patients with HCV-related compensated cirrhosis, are summarized in table 2. The age of patients with ribavirin combination therapy was significantly lower than that of patients with no treatment ( $\mathrm{p}=0.013$; Bonferroni test $)$ and interferon monotherapy ( $\mathrm{p}=0.030$; Bonferroni test). The platelet count of patients of ribavirin combination therapy was significantly higher than that of patients without treatment ( $\mathrm{p}=0.002$; Bonferroni test) and interferon monotherapy ( $\mathrm{p}=0.015$; Bonferroni test). The total cholesterol level of patients with interferon monotherapy was significantly lower than that of patients without treatment $(\mathrm{p}=$ 0.039; Bonferroni test). Low viral load rates of patients with interferon monotherapy were significantly higher than those of patients with ribavirin combination therapy $(\mathrm{p}=0.006$; Bonferroni test). There were no other significant differences in clinical features at the start of the first course of interferon monotherapy among the three groups.

Additional treatment duration of only 1 patient, who was diagnosed with hepatocellular carcinoma during additional treatment, was evaluated using the period from the start of the second course of interferon monotherapy 


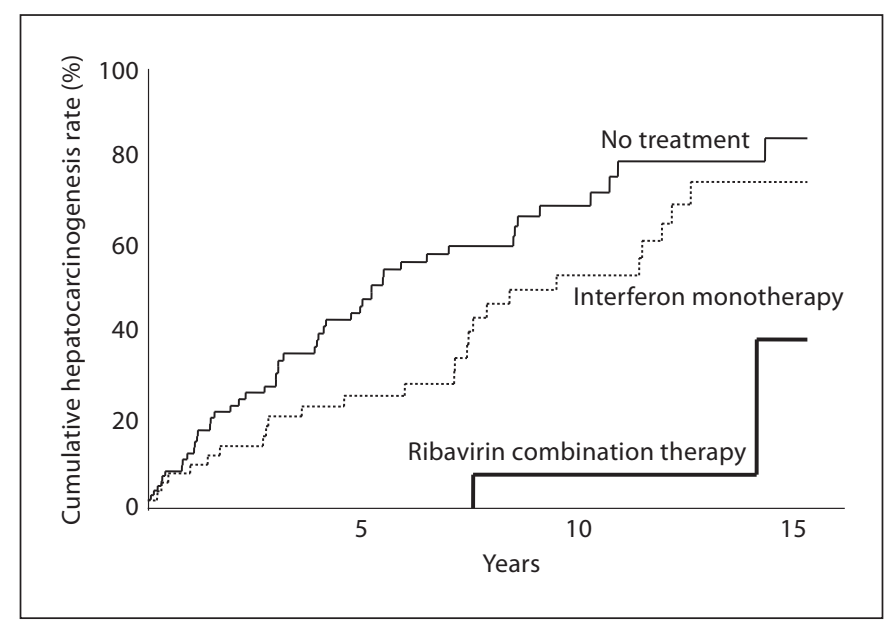

Fig. 3. Cumulative hepatocarcinogenesis rates in the three groups of additional treatment. The rates in no treatment were significantly higher than those in interferon monotherapy $(\mathrm{p}=0.047$; log-rank test) and ribavirin combination therapy ( $p<0.001$; logrank test), and the rates in interferon monotherapy were significantly higher than those in ribavirin combination therapy $(\mathrm{p}<$ 0.001 ; log-rank test).

Table 3. Factors associated with hepatocarcinogenesis in 185 patients of HCV-related compensated cirrhosis identified by multivariate analysis (study 2): Cox proportional hazard model

\begin{tabular}{lll}
\hline Factors/category & $\begin{array}{l}\text { Hazard ratio (95\% } \\
\text { confidence interval) }\end{array}$ & $\mathrm{p}$ \\
\hline $\begin{array}{l}\text { Additional treatment } \\
\quad \text { Ribavirin combination therapy }\end{array}$ & 1 & \\
$\quad \begin{array}{l}\text { Interferon monotherapy } \\
\quad \text { No treatment }\end{array}$ & $4.47(1.04-19.3)$ & 0.045 \\
$\begin{array}{l}\text { Age } \\
\quad<55 \text { years }\end{array}$ & 1 & 0.002 \\
$\quad \geq 55$ years & $2.87(1.76-4.67)$ & $<0.001$ \\
$\begin{array}{l}\text { Aspartate aminotransferase } \\
\quad<58 \text { IU/1 }\end{array}$ & 1 & \\
$\quad \geq 58$ IU/1 & $2.11(1.20-3.74)$ & 0.010 \\
\hline
\end{tabular}

until the appearance of hepatocellular carcinoma. During additional treatment, the total duration of interferon monotherapy was significantly longer than that of ribavirin combination therapy ( $\mathrm{p}=0.044$; Mann-Whitney $\mathrm{U}$ test). In ITT analysis, sustained virological response rates of ribavirin combination therapy (29\%) were not different from those of interferon monotherapy (20\%), but sustained biochemical response rates of ribavirin combina- tion therapy (67\%) tended to be higher than those of interferon monotherapy $\left(45 \% ; \mathrm{p}=0.083 ; \chi^{2}\right.$ test) (table 2 ).

\section{Predictive Factors Associated with}

\section{Hepatocarcinogenesis by Multivariate Analysis}

The data for the whole population sample were analyzed to determine those factors that could predict hepatocarcinogenesis. Hepatocarcinogenesis rates in older patients ( $\geq 55$ years), in patients with higher levels of aspartate aminotransferase $(\geq 58 \mathrm{IU} / \mathrm{l})$, and lower levels of platelet count $\left(<15.0 \times 10^{4} / \mathrm{mm}^{3}\right)$ were significantly higher than those in younger patients ( $<55$ years), in patients with lower levels of aspartate aminotransferase $(<58 \mathrm{IU} / \mathrm{l})$, and higher levels of platelet count $\left(\geq 15.0 \times 10^{4} / \mathrm{mm}^{3}\right)$, respectively $(\mathrm{p}<0.001, \mathrm{p}=0.006$, and $\mathrm{p}=0.017$; log-rank test). Furthermore, the rates in no treatment were significantly higher than those in interferon monotherapy $(\mathrm{p}=$ 0.047 ; log-rank test) and ribavirin combination therapy ( $\mathrm{p}$ $<0.001$; log-rank test), and the rates in interferon monotherapy were significantly higher than those in ribavirin combination therapy ( $\mathrm{p}<0.001$; log-rank test) (fig. 3). Thus, univariate analysis identified four parameters that significantly correlated with hepatocarcinogenesis. These factors were entered into multivariate analysis, which then identified three parameters that significantly influenced hepatocarcinogenesis independently: additional treatment (no treatment; HR 9.14, $\mathrm{p}=0.002)$, age $(\geq 55$ years; HR 2.87, p < 0.001), and levels of aspartate aminotransferase ( $\geq 58$ IU/1; HR 2.11, $\mathrm{p}=0.010)$ (table 3).

The data for 167 patients, except for 18 patients who showed a sustained virological response following additional treatment, were also analyzed to determine those factors that could predict hepatocarcinogenesis. Hepatocarcinogenesis rates in older age ( $\geq 55$ years) and higher levels of aspartate aminotransferase ( $\geq 58 \mathrm{IU} / \mathrm{l})$ were significantly higher than those in younger age $(<55$ years) and lower levels of aspartate aminotransferase $(<58 \mathrm{IU} / \mathrm{l})$, respectively $(p<0.001$ and $p=0.007 ; \log$-rank test). Furthermore, the rates in ribavirin combination therapy were significantly lower than those in interferon monotherapy ( $\mathrm{p}<0.001$; log-rank test) and no treatment ( $\mathrm{p}<$ 0.001; log-rank test) (fig. 4). Thus, univariate analysis identified three parameters that significantly correlated with hepatocarcinogenesis. These factors were entered into multivariate analysis, which then identified three parameters that significantly influenced hepatocarcinogenesis independently: additional treatment (no treatment; HR 7.87, $\mathrm{p}=0.005$ ), age ( $\geq 55$ years; $\mathrm{HR} 2.52, \mathrm{p}<$ $0.001)$, and levels of aspartate aminotransferase $(\geq 58$ IU/l; HR 2.13, $\mathrm{p}=0.010$ ) (table 4). 


\section{Discussion}

One of our previous studies indicated that the cancersuppressive activity of interferon monotherapy in patients with HCV-RNA eradication was similar to that in patients with alanine aminotransferase normalization without HCV-RNA elimination [9]. Other studies also indicated a higher incidence and more rapid development of hepatocellular carcinoma in HCV patients with high levels of alanine aminotransferase $[13,14]$. Collectively, these results suggest that the carcinogenic process in patients with chronic HCV infection is enhanced by high levels and fluctuations of alanine aminotransferase, and indicate a close relationship between suppression of inflammatory necrosis of hepatocytes and a lower incidence of hepatocellular carcinoma in patients with HCVassociated chronic liver disease. Recent studies based on interferon plus ribavirin combination therapy also showed that the attainment of sustained virological response or lower levels of alanine aminotransferase after ribavirin combination therapy could reduce the rates of hepatocellular carcinoma $[15,16]$, but the small numbers of patients with compensated cirrhosis (5\% or less of all patients) were recruited. The present study 1 based on the patients with compensated cirrhosis showed that rates of sustained virological response and sustained biochemical response in $\mathrm{HCV}-2 \mathrm{a} / 2 \mathrm{~b}$ were high rates of 70 and $78 \%$, and that rates of sustained biochemical response (57\%) were significantly higher than those of sustained virological response (34\%) in HCV-1b. Furthermore, the present study 2 based on the patients with compensated cirrhosis, who showed no sustained virological response following the first course of interferon monotherapy, also showed that sustained biochemical response rates of ribavirin combination therapy (67\%) tended to be higher than those of interferon monotherapy (45\%). Thus, in ribavirin combination therapy for compensated cirrhosis, higher rates of sustained biochemical response might be associated with lower rates of hepatocarcinogenesis. One limitation is that the present study was performed based on the small numbers of patients who showed no sustained virological response with interferon monotherapy. In further prospective studies a larger number of patients need to be investigated to confirm this finding.

Previous studies have shown that gender, age, fibrosis stage, alanine aminotransferase, and interferon regimen are important pretreatment predictors of hepatocarcinogenesis $[9,10,17]$. In the present study 2 based on the patients with compensated cirrhosis, higher age and aspartate aminotransferase were associated with higher hepa-

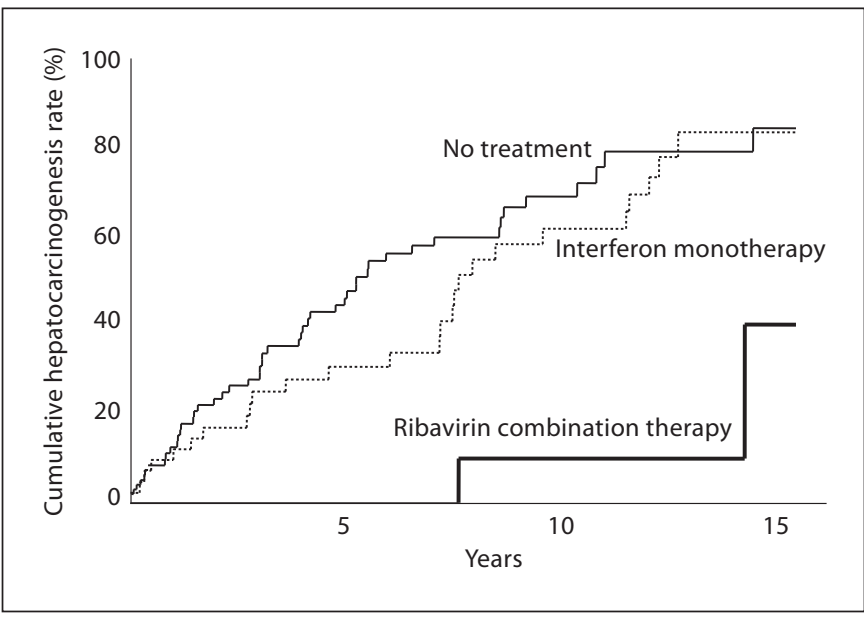

Fig. 4. Cumulative hepatocarcinogenesis rates in the three groups of additional treatment, except for patients who showed sustained virological response following additional treatment. The rates in ribavirin combination therapy were significantly lower than those in interferon monotherapy $(p<0.001$; log-rank test) and no treatment $(\mathrm{p}<0.001 ;$ log-rank test).

Table 4. Factors associated with hepatocarcinogenesis in 167 patients of HCV-related compensated cirrhosis, except for 18 patients who showed sustained virological response following additional treatment identified by multivariate analysis (study 2): Cox proportional hazard model

\begin{tabular}{|c|c|c|}
\hline Factors/category & $\begin{array}{l}\text { Hazard ratio }(95 \% \\
\text { confidence interval) }\end{array}$ & $\mathrm{p}$ \\
\hline \multicolumn{3}{|l|}{ Additional treatment } \\
\hline Ribavirin combination therapy & 1 & \\
\hline Interferon monotherapy & $4.68(1.08-20.3)$ & 0.039 \\
\hline No treatment & $7.87(1.89-32.9)$ & 0.005 \\
\hline \multicolumn{3}{|l|}{ Age } \\
\hline$<55$ years & 1 & \\
\hline$\geq 55$ years & $2.52(1.54-4.11)$ & $<0.001$ \\
\hline \multicolumn{3}{|l|}{ Aspartate aminotransferase } \\
\hline$<58 \mathrm{IU} / 1$ & 1 & \\
\hline$\geq 58 \mathrm{IU} / 1$ & $2.13(1.20-3.79)$ & 0.010 \\
\hline
\end{tabular}

tocarcinogenesis rates in the whole population sample and in the sample which excluded patients who showed sustained virological response following additional treatment. Furthermore, as treatment-related factors, the hepatocarcinogenesis rates in ribavirin combination therapy were significantly lower than those in interferon monotherapy. Thus, in patients with compensated cirrhosis representing a high-risk group of hepatocarcino- 
genesis, ribavirin combination therapy might reduce the risk of hepatocellular carcinoma in comparison with interferon monotherapy. One reason for the higher anticarcinogenic activity by ribavirin combination therapy might be due to higher rates of sustained biochemical response. The other reason might be due to the difference in the background (lower age and higher levels of platelet count as an indicator of fibrosis stage) of patients with ribavirin combination therapy. Further studies of a larger number of patients matched for background, including age, sex, genotype, and platelet count, are required to investigate the rates of hepatocarcinogenesis and the mechanism of anticarcinogenic activity by ribavirin combination therapy for HCV-related compensated cirrhosis.

Two previous studies (PROVE1 and PROVE2) showed that the 12- and 24-week regimen of telaprevir/PEG-IFN/ ribavirin could achieve sustained virological response rates of $35-60$ and $61-69 \%$ in patients infected with HCV1 , respectively $[18,19]$. However, a recent study (PROVE3) also showed that the sustained virological response rates were the lower rates of 39 and $38 \%$ with the 24 - and 48 week regimen of triple therapy in previously nonresponding patients infected with HCV-1, who do not become HCV-RNA negative during or at the end of the initial PEG-IFN/ribavirin treatment, respectively [20]. Furthermore, the telaprevir-based regimen induces resistant variants [21-23] and has side effects including anemia and rash $[18-20,24]$. Hence, patients, who do not achieve sustained virological response by triple therapy, need to be identified, in order to avoid unnecessary side effects and telaprevir-resistant variants. Recent studies identified amino acid substitutions at position 70 and/or 91 in the HCV-1b core region, advanced fibrosis stage, and higher levels of $\alpha$-fetoprotein as pretreatment predictors of poor virological response to PEG-IFN/ribavirin combination therapy or triple therapy of telaprevir/PEG-IFN/ ribavirin [23, 25-28], and these factors are also risk factors and surrogate markers of hepatocarcinogenesis [2934]. Hence, ribavirin combination therapy for these patients might be an efficacious therapeutic regimen for sustained biochemical response and thus a reduction of the risk of hepatocarcinogenesis. Large-scale prospective studies should be conducted in the future to confirm this finding.

In conclusion, the present retrospective study indicated that ribavirin combination therapy for HCV-related compensated cirrhosis could reduce the risk of hepatocarcinogenesis in comparison with interferon monotherapy. Large-scale prospective studies need to be conducted in the future to confirm these findings.

\section{Acknowledgments}

This study was supported in part by a Grant-in-Aid from the Ministry of Health, Labor and Welfare, Japan.

\section{References}

1 Niederau C, Lange S, Heintges T, Erhardt A, Buschkamp M, Hürter D, Nawrocki $M$, Kruska L, Hensel F, Petry W, Häussinger D: Progress of chronic hepatitis C: results of a large, prospective cohort study. Hepatology 1998;28:1687-1695.

2 Dusheiko GM: The natural course of chronic hepatitis C: implications for clinical practice. J Viral Hepatol 1998;5(suppl 1):9-12.

3 Ikeda K, Saitoh S, Suzuki Y, Kobayashi M, Tsubota A, Koida I, Arase Y, Fukuda M, Chayama K, Murashima N, Kumada H: Disease progression and hepatocellular carcinogenesis in patients with chronic viral hepatitis: a prospective observation of 2,215 patients. J Hepatol 1998;28:930-938.

4 Kenny-Walsh E: Clinical outcomes after hepatitis $\mathrm{C}$ infection from contaminated anti-D immune globulin. Irish Hepatology Research Group. N Engl J Med 1999;340:12281233.
5 Akuta N, Chayama K, Suzuki F, Someya T, Kobayashi M, Tsubota A, Suzuki Y, Saitoh S, Arase Y, Ikeda K, Kumada H: Risk factors of hepatitis $\mathrm{C}$ virus-related liver cirrhosis in young adults: positive family history of liver disease and transporter associated with antigen processing 2 (TAP2) * 0201 allele. J Med Virol 2001;64:109-116.

6 Davis GL, Balart LA, Schiff ER, Lindsay K, Bodenheimer HC Jr, Perrillo RP, Carey W, Jacobson IM, Payne J, Dienstag JL, VanThiel DH, Tamburro C, Lefkowitch J, Albrecht J, Meschievitz C, Ortego TJ, Gibas A: Treatment of chronic hepatitis $\mathrm{C}$ with recombinant interferon alfa. A multicenter randomized, controlled trial. Hepatitis Interventional Therapy Group. N Engl J Med 1989; 321:1501-1506.
7 Di Bisceglie AM, Martin P, Kassianides C, Lisker-Melman M, Murray L, Waggoner J, Goodman Z, Banks SM, Hoofnagle JH: Recombinant interferon alfa therapy for chronic hepatitis C. A randomized, double-blind, placebo-controlled trial. N Engl J Med 1989; 321:1506-1510.

-8 Nishiguchi S, Kuroki T, Nakatani S, Morimoto H, Takeda T, Nakajima S, Shiomi S, Seki S, Kobayashi K, Otani S: Randomised trial of effects of interferon-alpha on incidence of hepatocellular carcinoma in chronic active hepatitis C with cirrhosis. Lancet 1995;346: 1051-1055.

-9 Ikeda K, Saitoh S, Arase Y, Chayama K, Suzuki Y, Kobayashi M, Tsubota A, Nakamura I, Murashima N, Kumada H, Kawanishi M: Effect of interferon therapy on hepatocellular carcinogenesis in patients with chronic hepatitis type C: a long-term observation study of 1,643 patients using statistical bias correction with proportional hazard analysis. Hepatology 1999;29:1124-1130. 
10 Yoshida H, Shiratori Y, Moriyama M, Arakawa $\mathrm{Y}$, Ide $\mathrm{T}$, Sata $\mathrm{M}$, Inoue $\mathrm{O}$, Yano $\mathrm{M}$, Tanaka M, Fujiyama S, Nishiguchi S, Kuroki $\mathrm{T}$, Imazeki $\mathrm{F}$, Yokosuka $\mathrm{O}$, Kinoyama $\mathrm{S}$, Yamada G, Omata M: Interferon therapy reduces the risk for hepatocellular carcinoma: national surveillance program of cirrhotic and noncirrhotic patients with chronic hepatitis C in Japan. IHIT Study Group. Inhibition of Hepatocarcinogenesis by Interferon Therapy. Ann Intern Med 1999;131:174-181.

-11 Lok AS, Everhart JE, Wright EC, Di Bisceglie AM, Kim HY, Sterling RK, Everson GT, Lindsay KL, Lee WM, Bonkovsky HL, Dienstag JL, Ghany MG, Morishima C, Morgan TR, HALT-C Trial Group: Maintenance peginterferon therapy and other factors associated with hepatocellular carcinoma in patients with advanced hepatitis C. Gastroenterology 2011;140:840-849.

$\checkmark 12$ Chayama K, Tsubota A, Arase Y, Saitoh S, Koida I, Ikeda K, Matsumoto T, Kobayashi M, Iwasaki S, Koyama S, Morinaga T, Kumada $\mathrm{H}$ : Genotypic subtyping of hepatitis $\mathrm{C}$ virus. J Gastroenterol Hepatol 1993;8:150156.

-13 Arase Y, Ikeda K, Murashima N, Chayama K, Tsubota A, Koida I, Suzuki Y, Saitoh S, Kobayashi $\mathrm{M}$, Kumada $\mathrm{H}$ : The long-term efficacy of glycyrrhizin in chronic hepatitis C patients. Cancer 1997;79:1494-1500.

-14 Tarao K, Rino Y, Ohkawa S, Shimizu A, Tamai S, Miyakawa K, Aoki H, Imada T, Shindo K, Okamoto N, Totsuka S: Association between high serum alanine aminotransferase levels and more rapid development and higher rate of incidence of hepatocellular carcinoma in patients with hepatitis $C$ virus-associated cirrhosis. Cancer 1999;86:589-595.

- 15 Kurokawa M, Hiramatsu N, Oze T, Mochizuki $\mathrm{K}$, Yakushijin T, Kurashige N, Inoue Y, Igura T, Imanaka K, Yamada A, Oshita M, Hagiwara H, Mita E, Ito T, Inui Y, Hijioka T, Yoshihara $\mathrm{H}$, Inoue A, Imai Y, Kato M, Kiso S, Kanto T, Takehara T, Kasahara A, Hayashi $\mathrm{N}$ : Effect of interferon alpha-2b plus ribavirin therapy on incidence of hepatocellular carcinoma in patients with chronic hepatitis. Hepatol Res 2009;39:432-438.

16 Watanabe S, Enomoto N, Koike K, Izumi N, Takikawa H, Hashimoto E, Moriyasu F, Kumada $H$, Imawari $M$, PERFECT Study Group: Cancer preventive effect of pegylated interferon $\alpha-2 b$ plus ribavirin in a real-life clinical setting in Japan: PERFECT interim analysis. Hepatol Res 2011;41:955-964.

$\checkmark 17$ Hino K, Kitase A, Satoh Y, Fujiwara D, Yamaguchi Y, Korenaga M, Shingai Y, Konishi T, Yamashita S, Uchida K, Mori K, Hanada $\mathrm{H}$, Kodama T, Nukui K, Okita K: Interferon retreatment reduces or delays the incidence of hepatocellular carcinoma in patients with chronic hepatitis C. J Viral Hepat 2002;9:370-376.
18 McHutchison JG, Everson GT, Gordon SC, Jacobson IM, Sulkowski M, Kauffman R, McNair L, Alam J, Muir AJ, PROVE1 Study Team: Telaprevir with peginterferon and ribavirin for chronic HCV genotype 1 infection. N Engl J Med 2009;360:1827-1838.

19 Hézode C, Forestier N, Dusheiko G, Ferenci P, Pol S, Goeser T, Bronowicki JP, Bourlière M, Gharakhanian S, Bengtsson L, McNair L, George S, Kieffer T, Kwong A, Kauffman RS, Alam J, Pawlotsky JM, Zeuzem S, PROVE2 Study Team: Telaprevir and peginterferon with or without ribavirin for chronic HCV infection. N Engl J Med 2009;360:18391850.

20 McHutchison JG, Manns MP, Muir AJ, Terrault NA, Jacobson IM, Afdhal NH, Heathcote EJ, Zeuzem S, Reesink HW, Garg J, Bsharat M, George S, Kauffman RS, Adda N, Di Bisceglie AM, PROVE3 Study Team: Telaprevir for previously treated chronic HCV infection. N Engl J Med 2010;362:1292-1303.

- 21 Lin C, Gates CA, Rao BG, Brennan DL, Fulghum JR, Luong YP, Frantz JD, Lin K, Ma S, Wei YY, Perni RB, Kwong AD: In vitro studies of cross-resistance mutations against two hepatitis $\mathrm{C}$ virus serine protease inhibitors, VX-950 and BILN 2061. J Biol Chem 2005; 280:36784-36791.

22 Kieffer TL, Sarrazin C, Miller JS, Welker MW, Forestier N, Reesink HW, Kwong AD, Zeuzem S: Telaprevir and pegylated interferon-alpha-2a inhibit wild-type and resistant genotype 1 hepatitis $C$ virus replication in patients. Hepatology 2007;46:631-639.

-23 Akuta N, Suzuki F, Seko Y, Kawamura Y, Sezaki H, Suzuki Y, Hosaka T, Kobayashi M, Kobayashi M, Saitoh S, Arase Y, Ikeda K, Kumada H: Determinants of response to triple therapy of telaprevir, peginterferon and ribavirin in prior non-responders infected with HCV genotype 1. J Med Virol 2012;84:10971105.

24 Kumada H, Toyota J, Okanoue T, Chayama K, Tsubouchi H, Hayashi N: Telaprevir with peginterferon and ribavirin for treatmentnaive patients chronically infected with HCV of genotype 1 in Japan. J Hepatol 2012; $56: 78-84$.

25 Akuta N, Suzuki F, Sezaki H, Suzuki Y, Hosaka T, Someya T, Kobayashi M, Saitoh S, Watahiki S, Sato J, Matsuda M, Kobayshi M, Arase Y, Ikeda K, Kumada H: Association of amino acid substitution pattern in core protein of hepatitis $C$ virus genotypelb high viral load and non-virological response to interferon-ribavirin combination therapy. Intervirology 2005;48:372-380.
26 Akuta N, Suzuki F, Kawamura Y, Yatsuji H, Sezaki H, Suzuki Y, Hosaka T, Kobayashi M, Kobayashi M, Arase Y, Ikeda K, Kumada H: Predictive factors of early and sustained responses to peginterferon plus ribavirin combination therapy in Japanese patients infected with hepatitis $C$ virus genotype $1 \mathrm{~b}$ : amino acid substitutions in the core region and lowdensity lipoprotein cholesterol levels. J Hepatol 2007;46:403-410.

27 Akuta N, Suzuki F, Hirakawa M, Kawamura Y, Yatsuji H, Sezaki H, Suzuki Y, Hosaka T, Kobayashi M, Kobayashi M, Saitoh S, Arase Y, Ikeda K, Chayama K, Nakamura Y, Kumada $\mathrm{H}$ : Amino acid substitution in $\mathrm{HCV}$ core region and genetic variation near IL28B gene predict viral response to telaprevir with peginterferon and ribavirin. Hepatology 2010;52:421-429.

28 Donlin MJ, Cannon NA, Yao E, Li J, Wahed A, Taylor MW, Belle SH, Di Bisceglie AM, Aurora R, Tavis JE: Pretreatment sequence diversity differences in the full-length hepatitis $C$ virus open reading frame correlate with early response to therapy. J Virol 2007; 81:8211-8224.

29 Ikeda K, Arase Y, Saitoh S, Kobayashi M, Someya T, Hosaka T, Akuta N, Suzuki Y, Suzuki F, Sezaki H, Kumada H, Tanaka A, Harada H: Prediction model of hepatocarcinogenesis for patients with hepatitis $\mathrm{C}$ virusrelated cirrhosis. Validation with internal and external cohorts. J Hepatol 2006;44: 1089-1097.

- 30 Akuta N, Suzuki F, Kawamura Y, Yatsuji H, Sezaki H, Suzuki Y, Hosaka T, Kobayashi M, Kobayashi M, Arase Y, Ikeda K, Kumada H: Amino acid substitutions in the hepatitis $\mathrm{C}$ virus core region are the important predictor of hepatocarcinogenesis. Hepatology 2007; 46:1357-1364.

- 31 Fishman SL, Factor SH, Balestrieri C, Fan X, Dibisceglie AM, Desai SM, Benson G, Branch AD: Mutations in the hepatitis C virus core gene are associated with advanced liver disease and hepatocellular carcinoma. Clin Cancer Res 2009;15:3205-3213.

$32 \mathrm{Hu}$ Z, Muroyama R, Kowatari N, Chang J, Omata M, Kato N: Characteristic mutations in hepatitis $\mathrm{C}$ virus core gene related to the occurrence of hepatocellular carcinoma. Cancer Sci 2009;100:2465-2468.

33 Nakamoto S, Imazeki F, Fukai K, Fujiwara K, Arai M, Kanda T, Yonemitsu Y, Yokosuka O: Association between mutations in the core region of hepatitis $C$ virus genotype 1 and hepatocellular carcinoma development. J Hepatol 2010;52:72-78.

34 Akuta N, Suzuki F, Seko Y, Kawamura Y, Sezaki H, Suzuki Y, Hosaka T, Kobayashi M, Hara T, Kobayashi M, Saitoh S, Arase Y, Ikeda K, Kumada H: Complicated relationships of amino acid substitution in HCV core region and $I L 28 B$ genotype influencing hepatocarcinogenesis. Hepatology 2012, E-pub ahead of print. 